Jurnal IImiah Potensia, 2019, Vol. 4 (2), 131-140

https://ejournal.unib.ac.id/index.php/potensia

e-issn: 2621-2382 p-issn: 2527-9270

\title{
Perkembangan Motorik Halus Anak Usia Dini Melalui Kolase Media Serutan Pensil
}

\author{
Dwi Nomi Pura ${ }^{1}$ \\ miminao26@gmail.com
}

Asnawati $^{2}$

\section{1, 2 Universitas Dehasen Bengkulu}

\begin{abstract}
Setiap individu anak usia dini memiliki potensi untuk mengalami masalah. Salah satu masalah individu tersebut adalah perkembangan motorik halus. Perkembangan motorik halus ini berkaitan dengan pengembangan kemampuan dalam menggunakan jari untuk menggunakan berbagai kegiatan, seperti melakukan gerakan (motion), menempel, mencubit, memotong, melukis, dan lain-lain. Masalah perkembangan motorik halus ini ditemukan pada anak usia 5-6 tahun di tempat penelitian. Salah satu solusi dari mengatasi masalah pada perkembangan motorik halus adalah dengan mengadakan kegiatan kolase dengan media serutan pensil. Tujuan penelitian ini adalah untuk mengetahui aktivitas kolase dengan media serutan pensil pada perkembangan motorik halus anak-anak. Penelitian ini menggunakan metode penelitian kualitatif deskriptif dengan menggunakan instrument penelitian berupa lembar observasi, dokumentasi dan wawancara. Total sampel sejumlah 13 anak. Hasil dari penelitiannya adalah, sejumlah 11 anak memiliki perkembangan yang sangat baik dan 2 orang belum berkembang dengan baik. Penyebab anak yang belum berkembang dipengaruhi oleh perundungan secara verbal oleh anak lain, karena anak ini selalu ingin membantu orang lain menurut persepsinya, tetapi menurut persepsi anak lain hal ini dianggap mengganggu.
\end{abstract}

Keywords: Strategi pembelajaran, Literasi Sains, Anak Usia Dini.

How to cite this article:

Pura, D., \& Asnawati, A. (2019). Perkembangan Motorik Halus Anak Usia Dini Melalui Kolase Media Serutan Pensil. Jurnal IImiah POTENSIA, 4(2), 131-140. doi:https://doi.org/10.33369/jip.4.2.131-140

\section{PENDAHULUAN}

Undang-undang nomor 20 tentang system pendidikan nasional pasal 1 angka 14 menyatakan bahwa, Pendidikan Anak Usia Dini adalah suatu upaya pembinaan yang ditujukan kepada anak sejak lahir sampai dengan usia enam tahun, yang dilakukan melalui pemberian rangsangan pendidikan untuk membantu pertumbuhan dan perkembangan jasmani dan rohani, agar anak memiliki kesiapan dalam memasuki pendidikan lebih lanjut. Pendidikan Anak Usia Dini (PAUD) merupakan salah satu bentuk penyelenggaraan pendidikan yang menitik beratkan pada pertumbuhan dan perkembangan fisik motorik (motoric halus dan motoric kasar) kecerdasan sosial emosional, kecerrdasan spiritual, kecerdasan bahasa dan kecerdasan kognitif. Dalam Kurikulum Taman Kanak-Kanak (2010) dijelaskan bahwa tujuan taman Kanak-Kanak adalah sebagai berikut:

(a) Membangun landasan bagi berkembangnya potensi peserta didik agar menjadi manusia beriman dan bertakwa 
kepada Tuhan Yang Maha Esa berahlak mulia berkepribadian luhur, sehat, berilmu, cakap, kritis, kreatuf, inovatif, mandiri, percaya diri dan menjadi warga Negara yang demokratis dan bertanggung jawab.

(b) Menggembangkan potensi kecerdasan spiritual, Intelektual, emosional, kinestetis, dan social peserta didik pada masa usia emas pertumbuhan dalam lingkungan bermain yang edukatif dan menyenangkan.

(c) Membantu peserta didik mengembangkan berbagai potensi baik fisikis dan fisik yang meliputi nilai-nilai agama dan moral, Sosial Emosional, Kemandirian,Kognitif, Bahasa, dan Fisik Motorik untuk siap memasuki pendidikan dasar.

Untuk mewujudkan tujuan tersebut dibutuhkan stimulasi yang tepat dalam mengembangkan kemampuan dasar yang terdiri dari aspek Fisik, bahasa, Nilai-nilai Moral dan Agama, Sosial Emosional dan Kognitif melalui metode belajar yang berpariasi, menarik bagi anak. Dan lingkungan yang mendukung agar perkembangan kemampuan anak tercapai secara optimal.

Aspek fisik meliputi pengembangan Motorik halus (fine Motor) dan motorik kasar (gross motor) yang berguna untuk pertumbuhan dan kesehatan anak. Perkembangan motorik halus merupakan perkembangan gerakan anak yang menggunakan otot kecil atau sebagian anggota tubuh tertentu yang dipengaruhi oleh kesempatan anak untuk belajar dan berlatih (Sumartini, 2011).

Motorik halus yang paling utama adalah kemampuan memegang dengan tepat yang diperlukan untuk menulis. Dari penjelasan diatas betapa pentingnya Motorik halus anak. Akan tetapi dalam praktek sehari-hari terdapat permasalahan dan perkembangan kemampuan motorik halus anak dari pengamatan peneliti masalah yang terjadi dalam kelompok anak
Paud Kasih Ibu Kecamatan Talang Empat Kabupaten Bengkulu Tengah kurangnya kemampuan motorik halus anak yaitu pada kegiatan kolase hanya anak yang sudah mampu dengan baik mengikuti kegiatan pembelajaran yang mengembangkan kegiatan motorik halus pada kegiatan kolase. Dalam kegiatan kolase kurangnya kosentrasi, kerapian, ketepatan, dan kemandirian anak dalam menempel dengan tepat pada pola yang dicontohkan oleh guru.

Dengan demikian perlu adanya pembelajaran yang kreatif dan inovatif dari guru misalnya dalam memilih atau menentukan strategi pembelajaran, memilih alat atau media, jenis dan bentuk sistem pembelajaran serta alat evaluasi hal ini dilakukan agar kegiatan yang dilaksanakan lebih menarik dan bias membangkitkan rasa ingin tahu anak dan memotivasi anak untuk berfikir kritis dan bisa menentukan hal-hal baru.

Dari penjelasan tersebut peneliti akan melakukan penelitian kualitatif dengan metode deskriptif. Perkembangan motorik halus Anak Usia Dini dengan kolase media serutan pensil. Karna kegiatan kolase merupakan salah satu bentuk keegiatan yang membutuhkan koordinasi antara mata dan tangan (Motorik Halus). Oleh sebab itu peneliti akan melakukan penelitian dengan judul "Perkembangan Motorik Halus Anak Usia Dini Melalui Kolase Media Serutan Pensil.

\section{METODE PENELITIAN}

Metode penelitian yang digunakan dalam penelitian ini adalah Metode Deskriptif Kualitatif. Penelitian kualitatif percaya bahwa kebenaran adalah dinamis dan dapat ditemukan hanya melalui penelaahan terhadap orang-orang melalui interaksinya dengan situasi sosial mereka (Danim, 2002).

Untuk mendapatkan data yang diperlukan dalam penelitian ini ada 
beberapa tehnik yang digunakan antara lain:

a. Metode wawancara, yaitu wawancara yang dilakukan dengan terlebih dahulu pewawancara mempersiapkan pedoman tertulis tentang apa yang akan titanyakan kepada informan.

b. Metode observasi partisipan, yaitu mengumpulkan data melalui pengamatan langsung terhadap aktivitas informan.

c. Dokumentasi adalah pencarian data mengenai hal- hal atau variabel yang berupa catatan, transkip, buku ,surat kabar dan sebagainya Arikunto (2002).

Teknik analisis data dalam penelitian ini terdiri dari beberapa tahapan sesuai dengan metode penelitian yang dilakukan melalui wawancara observasi dan dokumentasi sebagai berikut (Opet, 2012)

1. Mengumpulkan semua data yang didapat dari lapangan yang telah disusun oleh peneliti.

\section{Melakukan analisis dengan} membandingkan dan mencari hubungan serta menentukan pola dari data aslinya.

3.Dari analisis tersebut nantinya akan disusun dalam bentuk uraian.

4.Analisis data ini bertujuan untuk merefleksikan dari tindakan yang telah dilakukan dan akhirnya untuk menjawab pertanyaan penelitian. Kemudian menarik kesimpulan berdasarkan analisis yang telah dilakukan.

Penelitian ini dilakukan di PAUD Kasih

Ibu Kecamatan Talang Empat Bengkulu Tengah. Teknik keabsahan data komfirmitas digunakan sehingga menghasilkan hasil penelitian sesuai dengan keadaan real di lapangan

\section{HASIL DAN PEMBAHASAN}

Perkembangan motorik halus di PAUD Kasih Ibu, pada pola perkembangan atau tingkat pencapaian anak usia lima tahun sampai enam tahun yaitu; menggambar sesuai dengan gagasannya ,meniru bentuk,menempel dengan berbagai media, salah satunya menempel deagan media serutan pensil pada kolase sesuai dengan pola perkembangan motorik halus melibatkan otot-otot ujung jari dan bagian tubuh lain yang terlibat dalam motorik halus adalah pergelangan tangan atas atau bagian sendi bahu .Perkembangan motorik halus di PAUD Kasih Ibu dapat di latih dan di kembangakan melalui kegiatan seperti bermain puzzle menyusun balok dan kolase dari berbagai bahan salah satunya adalah kolase dari media serutan pensil. Perkembangan motorik halus ini mempunyai peranan yang penting dalam pengembangan seni. Selain itu perkembangan motorik halus sangat penting terutama pada saat anak memegang pensil atau alat tulis dengan baik dan benar. Selain itu juga sebagai kemampuan anak untuk mengamati sesuatu dan melakukan gerakan yang melibatkan bagian-bagian tubuh tertentu dan otot kecil serta memerlukan koordinasi yang tepat. Dalam perkembangan motorik halus pada anak usia dini, perkembangan motorik kasar yang terlebih dulu berkembang dibandingkan perkembangan motorik halus nya. Hal ini bisa dilihat ketika anak sudah bisa berjalan dengan menggunakan otot-otot kakinya kemudian anak baru mengontrol tangan dan jarijarinya untuk menulis, menggambar, menempel atau menggunting.

Motorik halus anak pada umumnya memerlukan jangka waktu yang cukup lama hal ini merupakan suatu proses bagi anak untuk mencapainya, maka pada anak usia dini perlu dilakukan kegiatan untuk perkembangan motorik halus anak salah salah satunya perkembangan motorik halus anak melalui kolase media serutan pensil. Perkembangan motorik halus setiap anak berbeda contohnya ada yang berjalan 
dengan cepat ada juga yang sesuai dengan perkembangannya tergantung pada kematangan anak. Faktor yang melatar belakangi keterlambatan perkembangan motorik halus anak di PAUD Kasih Ibu :

a. Kurangnya kesempatan untuk melakukan ekplorasi terhadap lingkungan sejak dini dan pola asuh orang tua yang cendrung overprotektif dan kurang dalam memberikan fasilitas dan rangsangan belajar.

b. Tidak memberikan kebebasan pada anak untuk mengerjakan aktifitas sendiri, sehingga anak terbiasa selalu ingin di bantu oleh orang lain dalam memenuhi kebutuhannya. Menurut peneliti perkembangan motorik halus anak usia dini ini kemampuan yang berhubungan dengan fisik yang melibatkan otot-otot kecil, koordinasi mata dan tangan.

c. Motorik halus ini dapat dilatih dan dikembangkan melalui kegiatan dan rangsangan yang berulang-ulang secara rutin ini dapat diterapkan pada permainan puzzle, menyusun balok, mengambar, melipat kertas dan salah satunya menempel kolase serutan pensil. Kecerdasan motorik halus anak berbeda-beda baik dalam hal kekuatan maupun ketepatan. Perbedaan ini dipengaruhi oleh pembawaan anak dan stimulasi yang didapatkannya. Salah satunya lingkungan (orang tua) mempunyai pengaruh yang lebih besar dalam kecerdasan motorik halus anak. Lingkungan dapat meningkatkan atau menurunkan taraf kecerdasan pada anak .terutama pada masa-masa pertama kehidupannya.

d. Anak-anak pada usia prasekolah mengkonselidasikan dan mengalami kemajuan dalam keterampilan fisik yang telah di kembangankannya tahun-tahun awal tantangan koordinasi sebelum ini di hindarinya, seperti melompat dengan satu kaki, melompat dengan ke dua kaki di angkat bersamaan dan menjaga keseimbangan dan dilakukan atau berusaha melakukan banyak aktifitas, tentu saja masih diperlukan waktu yang lama sebelum mencapai kompetensi total dalam bidang bidang ini agar anak lebih giat dari sebelumnya. Perbedaan dalam kemampuan bergerak pada anak di Paud Kasih Ibu pada usia anak prasekolah sangat mencolok anak senang mempraktekkan keterampilan fisik baru ini,baik dirumah, kelompok bermain atau ditaman kanak-kanak.

Gerakan motorik halus adalah gerakan yang melibatkan bagian-bagian tubuh tertentu saja dan dilakukan oleh otot-otot kecil, menggunakan jari tangan dan pergelangan tangan yang tepat gerakan ini membutuhkan koordinasi mata dan tangan yang cermat .gerakan motorik halus yang terlihat saat usia taman kanak-kanak antara lain anak mulai menyikat gigi, menyisir rambut, memakai tali sepatu sendiri dan sebagainya.perkembangan motorik halus merupakan proses memperoleh keterampilan pola gerakan yang dapat di lakukan anak misalnya dalam perkembangan motorik kasar anak belajar mengerakan seluruh atau sebagian besar anggota tubuh nya, sedangkan dalam mempelajari motorik halus anak belajar ketepatan koordinasi tangan dan mata anak juga belajar mengerakan pergelangan tangan agar lentur dan anak belajar berkreasi dan berimjinasi.menurut penelitian, semakin baik gerakan motorik halus anak sudah membuat anak dapat berkreasi seperti menempel media serutan pensil pada kolase gambar buah apel, sayur bayam, tanaman hias, tetapi tidak semua anak memiliki kematangan untuk menguasai kemampuan terhadap yang sama. Dalam melakukan gerakan motorik 
halus anak juga memerlukan dukungan keterampilan fisik serta kematangan mental.

Menurut peneliti fungsi motorik halus ini pada dasarnya sudah ada sejak lahir dan berkembang secara bertahap, kendati faktor bawaan atau hereditas dapat mempengaruhi perkembangan motorik halus, akan tetapi stimulasi jauh lebih berperan dengan kata lain meski anak dan tidak mengalami gangguan perkembangan stimulasi tetap diperlukan untuk lebih mengasah keterampilan tersebut sehingga dapat berkembang lebih baik karena motorik halus sendiri di artikan sebagai kemampuan yang menyatakan kemampuan fisik dengan melibatkan koordinasi otototot halus artinya tidak hanya lengan yang bergerak, kegiatan mencoret pun melibatkan pergerakan pergelangan tangan dan jari-jari .dengan begitu fleksibel /kelenturan telapak tangan dan jari-jari secara keseluruhan untuk melakukan aktifitas secara keseluruhan untuk melakukan aktifitas yang semakin terlatih ,diantaranya menyuapkan sendok berisi makanan kedalam mulut, mengunakan atau melepaskan pakaian maupun bermain dengan permainan yang membutuhkan koordinasi tangan.

Kematangan perkembangan motorik halus ini nantinya juga akan membantunya dalam menulis ,lebih baik dan tak cepat lelah saat harus banyak menyelesaikan tugas sekolah terkait dengan menulis. Menurut peneliti yang harus diperhatikan dalam perkembangan motorik halus anak agar berkembang optimal sesuai dengan perkembangan anak haruslah memperhatikan berbagai aspek yaitu:

a. Kesiapan belajar, keterampilan yang dipelajari dengan waktu dan usaha yang sama oleh orang yang sudah sap, hasilnya akan lebih baik jika di bandingkan dengan orang yang belum siap belajar. b. Kesempatan belajar, banyak yang tidak berkesempatan untuk mempelajari keterampilan motorik halus karena hidup dalam lingkungan yang tidak menyediakan belajar atau karena alasan lain.

c. kesempatan berpraktek, anak harus di beri waktu untuk berpraktek sebagai yang di perlukan.

d. Model yang baik, karena dalam mempelajari perkembangan motorik halus, Meniru suatu model, menanamkan peran yang penting, maka untuk itu anak harus melihat model yang baik.

e. Bimbingan, untuk dapat meniru model yang baik, maka membutuhkan bimbingan untuk membetulkan kesalahan.

f. Motivasi, motivasi belajar penting untuk mempertahankan ummat dari ketertinggalan .sumber motivasi umum adalah kepuasan pribadi anak dari suatu kegiatan yang sedang ia lakukan.

Usia lima tahun koordinasi motorik halus anak lebih sempurna lagi, tangan, lengan dan tubuh bergerak dibawah koordinasi mata. Anak juga mampu membuat dan melaksanakan kegiatan yang lebih majemuk sedangkan pada akhir masa kanak-kanak usia enam tahun ia telah belajar bagaimana mengunakan jari jemari tangan dan pergelangan tangannya untuk menggerakan ujung pensil. Motorik halus bisa dikembangkan dengan cara lain yaitu: anak menggali pasir dan tanah dan sebagainya. Sedangkan kompetensi dasar motorik halus diharapkan dapat dikembangkan oleh guru saat anak memasuki lembaga prasekolah, misalnya anak mampu. a). Melakukan aktivitas fisik secara terkoordinasi dalam rangka kelenturan dan kesiapan untuk menulis, keseimbangan kelincahan dan melatih keberanian. b). Mengekpresikan diri dan berkreasi dengan berbagai gagasan dan 
imajinasi dan menggunakan berbagai media/bahan menjadi suatu karya seni berupa kolase.

Menurut peneliti tujuan perkembangan motorik halus yaitu untuk keterampilan gerak tangan, mengkoordinasikan kecepatan, kecermatan, ketepatan dan keseimbangan.

Tujuan perkembangan motorik halus anak usia : a) sebagai untuk pengembangan keterampilan gerak kedua tangan. b) anak dapat menciptakan hasil karya yang orisinil (asli) dari anak tersebut. c) sebagai alat untuk pengembangan koordinasi kecepatan tangan dan mata. d) sebagai alat untuk melatih penguasaan emosi (egosentris nya) sangat tinggi.

Perkembangan motorik halus pada anak dapat dilatih dan dikembangkan melalui kegiatan seperti bermain puzzle menyusun balok dan kolase dari berbagai bahan salah satunya adalah kolase dari media serutan pensil. Pada penerapannya anak dapat belajar berfikir dengan cara terlibat langsung dalam kegiatan pada kolase media serutan pensil. Dengan diadakan nya penelitian ini guru dapati menunjukkan cara mengajar anak yang paling efektif dengan melibatkan kecenderungan alami mereka untuk belajar melalui permainan. Anak belajar banyak hal tentang dunia disekitar mereka dengan bermain. Anak akan memperoleh pengetahuan mereka dalam permainan kolase serutan pensil yang mereka lakukan. Belajar adalah hak anak maka belajar haruslah menyenangkan, kondusif dan meningkatkan anak menjadi termotivasi dan antusias. Memaksa anak untuk belajar sehingga anak merasa tertekan atau membiarkan anak tidak mendapat pendidikan yang layak adalah tindakan kekerasan.

Adapun teori yang digunakan dalam penelitian ini adalah teori Experiential Learning, teori Kontruktivisme dan Multiple Inteligences. Belajar menurut teori
Experiential Learning adalah Anak belajar melalui pengalaman yang dalam hal ini mempraktekkan suatu metode ilmiah.

a. Anak sebagai pembelajar, menghadapi pengalaman asli yakni keterlibatan aktif anak dalam suatu aktivitas yang menarik bagi mereka.

b. Dalam pengalaman ini anak menemukan berbagai masalah yang menstimulus mereka untuk berfikir.

c. Anak-anak memproses informasiinformasi yang ada disekitarnya dan melakukan serangkaian dugaan untuk mendapatkan informasi-informasi yang diperlukan untuk menyelesaikan masalah.

d. Anak mengembangkan berbagai kemungkinan solusi atau alternatif yang mungkin dapat menyelesaikan masalah.

Melalui perkembangan motorik halus, anak belajar dan memperoleh pengetahuan. Ini berarti pengetahuan bukanlah wujud informasi yang melekat otomatis pada anak yang diperoleh tanpa usaha. Pengetahuan merupakan suatu alat untuk menjelaskan masalah. Pengetahuan yang diperoleh melalui pengalaman dipergunakan sebagai materi untuk menyelesaikan masalah.

Semua ragam permainan yang telah disediakan oleh guru semua ragam permainan yang ada pada tiap-tiap sentra tersebut dapat digunakan anak sebagai sumber pengetahuan dan alat untuk mencoba belajar menyelesaikan masalah. Contohnya saja dalam kegiatan kolase serutan pensil anak dapat menempel dengan rapi dan baik.

Kegiatan kolase dilaksanakan untuk menstimulus perkembangan Motorik Halus Anak Usia Dini Kolase Media Serutan Pensil Paud Kasih Ibu. Potensi kecerdasan anak akan berkembang secara optimal bila dikembangkan sejak dini melalui layanan pendidikan yang tepat sesuai dengan tingkat perkembangan anak. Dari 
pemaparan tersebut terlihat bahwa penelitian ini relevan dengan teori belajar Experiential Learning teori ini berpendapat yaitu belajar adalah proses aktif yang menuntut peran aktif setiap anak.

Permasalahan

terhambatnya perkembangan motorik halus subjek An. G dan An. Y masih diupayakan oleh guru Paud tetapi belum melibatkan komunikasi dengan orang tua. Sehingga guru Paud kesulitan dalam membantu kedua anak tersebut. Untuk mencapai standar perkembangan motorik halus yang tercantum pada Permendikbud No. 58 Tahun 2009 tentang Standar Pendidikan Anak Usia Dini.

Hidayat dan Sari (2013), menyatakan bahwa perlu adanya kerja sama antara guru dengan masyarakat termasuk orangtua yang bersifat akademik dan non-akademik untuk perkembangan motorik halus pada anak. Salah satu alternatif kegiatan yang bias dilaksanakan untuk membantu anak yang mengalami masalah perkembangan motorik halus anak usia dini adalah dengan layanan bimbingan dan konseling. Bunu (2012) menyatakan pendapat bahwa layanan bimbingan konseling perlu diberikan konselor kepada anak terutama kegiatan layanan prefentif dan pengembangan layanan, bimbingan dan konseling yang dapat dilaksanakan adalah konsultasi. Hal ini sesuai dengan penelitian yang dilaksanakan oleh Anggraini dan Christian (2014) bahwa peran konselor di TK ABA 31 Wiyung yaitu sebagai konsultan (konsultasi bagi guru atau orangtua anak) bukan sebagai konselor langsung bagi anak. Apabila guru Paud tidak bisa menangani langsung pelaksanaannya penanganan konselor diberikan kepada anak langsung dilakukan secara insidental. Cara dan penanganan untuk prilaku percaya diri anak dilakukan dengan cara persuasif dengan terus menerus mremberikan bimbingan tanpa terkesan memberi tekanan. Layanan konsultasi dalam bimbingan dan konseling bukanlah layanan yang bersifat konsultasi pada umumnya.

Prayitno (2012), mengemukakan bahwa layanan konsultasi sebagai layanan konseling yang diberikan oleh konselor terhadap konsulti yang memungkinkan konsulti memperoleh wawasan pemahaman dan cara yang perlu dilaksanakan untuk menangani masalah pihak ketiga. Pihak ketiga yang dimaksud dalam hal ini adalah anak yang memiliki masalah perkembangan motorik halus.

Tekin (2012), menyatakan bahwa konselor perlu berkolaborasi dengan orangtua anak, guru untuk mengatasai permasalahan anak. Adanya sinergi antara konselor guru, orangtua dan anak diharapkan dapat memunculkan sebuah solusi untuk menangani masalah perkembangan motorik halus anak usia dini.

Metode bimbingan dan konseling lain yang dapat dilaksanakan konselor adalah metode bermain. Metode bermain dapat menjadi media layanan bimbingan dan konseling yang menarik bagi anak usia dini karena karakteristik anak usia dini yang masih senang bermain. Hal ini sesuai dengan penelitian evaluasi yang dilaksanakan oleh Kholili dan Ristian (2013), menyatakan metode bimbingan dan konseling yang diimplementasikan di TK Islam Surabaya adalah metode semi bermain dengan menggunakan media yang menarik dan bervariasi. Selain itu Sukiman (2013), juga memiliki gagasan bahwa eduplay counseling dapat digunakan sebagai salah satu alternatif upaya mengatasi tingkah laku anak pada praktek Paud. Bimbingan dengan mitode bermain sering di sebut dengan konsep play therapy (terapi bermain) .Menurut MC.Mahan (1992) bermain adalah perasaan dan perbuatan spontan dan aktif dimana pikiran perasaan dan perbuatan dapat berkembang atau gagal atau konsekuensi masalah Selanjutnya Cattanach mendefinisikan flay therapy adalah cara 
membantu masalah anak yang mengalami distres dengan mengunakan permainan sebagai komunikasi antara anak dan konselor.

Pengaruh kolase terhadap perkembangan motorik halus anak di Paud Kasih Ibu dapat di simpulkan bahwa pengaruh kolase media serutan pensil berpengaruh signifikan pada perkembangan motorik halus anak, hal ini dapat di lihat dari pengamatan yang di lakukan oleh peneliti dalam kegiatan pembelajaran dengan mengunakan kolase media serutan pensil ,ketika mengunakan media kolase serutan pensil hasil nya sangat berbeda karena dengan bermain kolase serutan pensil anak dapat terlibat langsung dalam membentuk, dan anak juga mampu berekplorasi sesuai dengan imajinasinya . Sehingga motori khalus anak berkembang secara optimal sesuai . dengan tahap perkembangan anak.dan juga dapat membimbing anak memiliki konsentrasi yang baik sangat penting agar anak dapat mengikuti proses pembelajaran di sekolah .juga melatih keberanian anak.

Kelemahan pada kegiatan kolase media serutan pensil dari 13 orang anak terdapat 2 orang anak yang perkembangan motorik halus nya terhambat yaitu : subjek An $G$ dan $A n Y$, kedua anak tersebut masih belum berkembangan di karenakan anak ini tidak mandiri, dan selalu mau mendapat perhatian yang lebih dari guru dan teman teman nya, serta pada kegiatan kolase serutan pensil selalu ingin di bimbimng, dan selalu di ingatkan setiap melakukan kegiatan.

Untuk mengatasi terhambatnya perkermbangan dari kedua anak tersebut agar perkembangan motorik halus anak berkembang optimal dan sesuai dengan perkembangannya maka peneliti menemukan solusi nya dengan memberikan bimbingan dan konseling pada kedua anak tersebut.dan untuk yang sudah baik di kompirmasikan dengan teori belajar.

\section{KESIMPULAN}

Perkembangan motorik halus anak usia dini bisa ditunjang dengan berbagai macam cara. Salah satu cara yang bisa mengkonstruksi hal tersebut adalah melalui kegiatan membuat kolase dengan menggunakan media hasil serutan pensil. Manfaat baik yang diperoleh anak jika mengikuti kegiatan membuat kolase ini adalah anak dapat melatih motorik halus, dapat mengembangkan kreatifitas, bisa melatih konsentrasi, bisa mengenal konsep warna, pola dan bentuk, bisa melatih ketekunan dan kepercayaan diri. Selain itu juga bisa melatih kesabaran dan emosionall pada anak.

Saran

Saran yang bisa dilakukan sebagai tindak lanjut dari artikel hasil penelitian ini adalah

1. Pada saat kegiatan membuat kolase berlangsung Anak dibiarkan untuk berkreasi sesuai dengan kemampuan yang mereka miliki.

2. Pola yang diberikan kepada anak pun hendak lebih menarik dan berukuran besar sehingga anak lebih mudah untuk mengisi ruang yang ada atau di sesuai kan dengan usia anak.

3. Dalam melakukan kegiatan kolase media yang digunakan lebih menarik seperti serutan pensil supaya anak tidak bosan dan anak lebih kreatif.

4. Berikan waktu yang cukup kepada anak dalam melakukan kegiatan kolase, serta pengawasan kepada anak boleh guru pendamping.

5. Selalu memberikan reward atau penghargaan kepada anak agar anak lebih termotivasi lagi dalam melaksanakan kegiatan yang diberikan oleh guru.

\section{DAFTAR PUSTAKA}

Arikunto, (2002). Prosedur Suatu Penelitian Pendekatan Praktek. Jakarta: PT. Rineka Cipta. 
Azhar, A. (2009). Media Pembelajaran. Jakarta: PT. Grafindo Persada.

Danim, S. (2002). Penelitian Kualitatif dan Kuantitatif. Remaja Rosda Karya

Dayton \& Kem, (1998). Media Pembelajaran. Jakarta: PT. Grafindo Persada

Depdiknas, (2005). Pedoman pembelajaran di Taman Kanak-kanak. Jakarta: Dirjen Pendidikan Dasar dan menengah.

Depdikbud, (2003). Kamus Besar Bahasa Indonesia. Jakarta: Balai Pustaka.

Dinar, P. W. 2007. Psikologi Anak Usia Dini. Surakarta : PT. Indeks

Gerlach dkk, (1971). Instructional Media Technology for Learning. Jakarta: PT. Grafindo Jakarta.

Gozansky, Y. (2017). From pupils to consumers: the transformation of the concept of childhood in Israeli children's television. Journal of Children and Media, 11(1), 36-52. https://doi.org/10.1080/17482798.201 6.1203809

Green, M., Mcneese, M. N., \& Mississippi, S. (2007). Using edutainment software to enhance online learning. International Journal on E-Learning, 6, 5-16. Retrieved from http://www.editlib.org/p/6317/

Haenilah, E. Y. (2015). Kurikulum dan pembelajaran PAUD. Yogyakarta: Media Akademi.

Kemmis, S., McTaggart, R., \& Nixon, R. (2013). The Action Research Planner: Doing Critical Participatory Action Research. Berlin: Springer Science \& Business Media.

Kurniah, N., Andreswari, D., \& Kusumah, R. G. T. (2019). Achievement of
Development on Early Childhood Based on National Education Standard. In Proceedings of the International Conference on Educational Sciences and Teacher Profession (ICETeP 2018) (pp. 351354). Paris, France: Atlantis Press. https://doi.org/10.2991/icetep18.2019 .82

Lagerlöf, P., Wallerstedt, C., \& Pramling, N. (2013). Engaging children's participation in and around a new music technology through playful framing. International Journal of Early Years Education, 21(4), 325335.

https://doi.org/10.1080/09669760.201 3.867170

Gusril \& Toho, (2004). Perkembangan Motorik Anak-anak. Jakarta: PT. Indeks.

Margono, (2009). Metode penelitian Pendidikan. Jakarta: Rineka Cipta.

Marsh, J. A. (2006). Emergent media literacy: Digital animation in early childhood. Language and Education, 20(6), 493506. https://doi.org/10.2167/le660.0

Moleong, L. J. (2008). Metodelogi Penelitian Klualitatif. Bandung Remaja Rosda Karya

Novitasari, R., Nasirun, M., \& D., D. (2019). MENINGKATKAN KEMAMPUAN MOTORIK KASAR ANAK MELALUI BERMAIN DENGAN MEDIA HULAHOOP PADA ANAK KELOMPOK B PAUD ALSYAFAQOH KABUPATEN REJANG LEBONG. Jurnal Ilmiah POTENSIA, 4(1), 6-12. https://doi.org/10.33369/jip.4.1.6-12

Pangastuty, A. G., Cahyana, U., \& Purwanto, A. (2017). PENGEMBANGAN MEDIA LECTUREMAKER 
DALAM PEMBELAJARAN KIMIA SMA POKOK BAHASAN IKATAN KIMIA MELALUI PENERAPAN PROFESSIONAL LEARNING COMMUNITY. JRPK: Jurnal Riset Pendidikan Kimia. https://doi.org/10.21009/jrpk.031.04

Putri, S. D., \& Citra, D. E. (2019). PROBLEMATIKA GURU DALAM MENGGUNAKAN MEDIA PEMBELAJARAN PADA MATA PELAJARAN IPS DI MADRASAH IBTIDAIYAH DARUSSALAM KOTA BENGKULU. IJSSE : Indonesian Journal of Social Science Education, 1(1), 49-54. Retrieved from

http://ejournal.iainbengkulu.ac.id/inde x.php/ijsse/article/view/49-54

Rantina, S., (2008). Master Kolase. Klaten: PT. Cemerlang Indonesia

Rudyanto \& Saputra, Y. M., (2005). Pembelajaran kooperatif meningkatkan keterampilan anak
Taman Kanak-Kanak. Jakrta : Depdiknas

Suyadi, (2010). Psikologi Belajar PAUD. Yogyakarta : PT. Pusaka Insani

Wati, K. I., Saparahayuningsih, S., \& Yulidesni, Y. (2017). Meningkatan Keterampilan Motorik Halus Anak Melalui Kegiatan Pembelajaran Membatik Menggunakan Media Tepung Pada Anak Kelompok B PAUD Aisyiyah III Kota Bengkulu. Jurnal Ilmiah POTENSIA, 2(2), 9194. https://doi.org/10.33369/jip.2.2

Wenno, I. H. (2008). Strategi Belajar Mengajar Sains Berbasis Kontekstual. Yogyakarta: Inti Media.

Xie, X., Gai, X., \& Zhou, Y. (2019). A metaanalysis of media literacy interventions for deviant behaviors. Computers \& Education, 139, 146156.

https://doi.org/10.1016/j.compedu.201 9.05.008 